\title{
Ideologia em problemas matemáticos nos livros didáticos soviéticos da pré-revolução até 1960
}

CIRCE MARY SILVA DA SILVA

Universidade Federal do Espírito

Santo, Vitória, ES, Brasil

VLADIMIR IVANOVITCH DYNNIKOV

Universidade Federal do Espírito

Santo, Vitória, ES, Brasil

\section{INTRODUÇÃO}

O livro escolar, como depositário de saberes construídos por gerações, tem inegavelmente seu papel pedagógico no processo de ensino e aprendizagem das disciplinas que constituem os currículos escolares. Todavia, ele não está isolado do contexto social, político e econômico que o circunda. Concebendo o livro didático como geográfico e historicamente determinado, ele é produto de uma certa sociedade num determinado tempo; por isso concordamos com Braudel (2009, p. 17) quando diz que "a história é filha de seu tempo".

Nos textos analisados no presente trabalho, pretendemos apresentar um recorte da história da educação matemática na União das Repúblicas Socialistas Soviéticas (URSS) no século XX, em que o livro didático de matemática ocupa um lugar de destaque.

Como os livros escolares teriam sido usados na divulgação da ideologia socialista, a fim de 'direcionarem' as jovens cabeças para a aceitação da crença da supremacia do regime soviético? O presente estudo aborda essa questão tomando como base a análise de livros didáticos de matemática produzidos na União Soviética no período pré-revolução até 1960. 
$\mathrm{O}$ alvo dos manuais escolares são primordialmente os alunos - a juventude - e também os professores. Mas a quem eles servem? Como qualquer escrito que está sempre permeado de ideologia, o livro didático também impregnado dela nos revela, a princípio, muito mais do que suspeitamos.

Para um embasamento teórico referente à questão de ideologia, fomos buscar um diálogo com Louis Althusser (1980). Para esse autor, é na escola que se aprende a ler, escrever, fazer cálculos e se obtém, portanto, saberes práticos necessários para a qualificação ao trabalho: "[...] a escola (mas também outras instituições como a igreja ou outros aparelhos como o exército) ensinam saberes práticos, mas em moldes que asseguram a sujeição à ideologia dominante ou ao manejo da prática desta" (1980, p. 22). A ideologia para esse autor é um sistema de ideias e de representações que possui tanto um indivíduo quanto um grupo social. Desde a escola primária, essa instituição assume por um tempo considerável a liderança como aparelho ideológico que irá, como nenhum outro, inculcar seu sistema de ideias e representações, tornando-se seu direcionador. Mas que ideias e diretrizes foram inseridas nos livros escolares a fim de moldar as novas gerações de cidadãos soviéticos? Em que época da formação do estudante iniciava-se a inculcação ideológica?

Para Deiró (1978, p. 26),

a burguesia, classe social dominante, para garantir sua hegemonia na sociedade capitalista, utiliza-se dos aparelhos ideológicos do Estado, sendo que o escolar assume a posição preponderante no conjunto desses aparelhos ideológicos, devido à sua eficácia na inculcação da ideologia dominante.

E como seria na sociedade não capitalista como a da antiga União Soviética? A fim de responder às questões propostas, servimo-nos basicamente de documentos originais - como os livros didáticos em língua russa e, assim, utilizamos uma metodologia qualitativa do tipo documental. A análise documental seguiu a seguinte trajetória: escolha do período a ser investigado, seleção de livros didáticos no período, seleção de categorias de análise para os livros.

O período escolhido compreende aquele que começa antes da Revolução Socialista e se estende até 1960. A escolha desse período justifica-se na medida em que, para responder à pergunta de investigação, necessitava-se conhecer o discurso dos livros de matemática utilizados antes da implantação do sistema educacional soviético até o momento em que este se consolida, com a corrida espacial.

Os livros analisados foram:

a) Seleção de problemas e exemplos de aritmética para séries iniciais das escolas do povo. Quarto ano, por Argennikov ${ }^{1}$ (1916) (Figura 1);

1 Para facilitar a referência dos nomes de autores russos, utilizamos no corpo do texto a versão latina deles. 
b) Seleção de problemas e exercícios de aritmética para escola média (7 anos). Quinto ano de estudo, organizada por Berezanskaya (1933) (Figura 2);

c) um conjunto de livros didáticos (teóricos) e livros de problemas e exercícios aritméticos, preparados por Popova $(1933,1937,1940,1941)$ para as séries iniciais $^{2}$ (Figura 3), individualmente e em coautoria com Ptchelko (Popova; Ptchelko, 1941);

d) Seleção de problemas em álgebra. Parte 1 para $6^{\circ}$ e $7^{\circ}$ anos de escola média, preparada por Láritchev ${ }^{3}$ (1958) (Figura 4).

e) Resolução de problemas aritméticos na escola inicial, por Nikitin (1939).

A primeira obra, a de 1916, justifica ser escolhida, pois era necessário sabermos qual o discurso ideológico das obras anteriores à revolução, para que fosse estabelecida uma comparação com o discurso da pós-revolução e identificar se houve alguma mudança. $\mathrm{O}$ segundo foi escolhido por ser um dos primeiros livros ${ }^{4}$ escritos por uma das mulheres docentes de matemática para o ensino médio seguindo as orientações do CC PCU (b); o terceiro, escrito também por uma professora que se dedicou a publicações para o ensino das séries iniciais e com um texto carregado de ideologia soviética; e o quarto pelo alcance significativo que teve em suas muitas edições e por sua estabilidade.

2 Popova escreveu três livros teóricos com alguns problemas para as quatro séries iniciais; desses, o terceiro livro era destinado para a terceira e quarta séries. Escreveu também quatro livros com coletânea de exercícios e problemas para as quatro séries, mas não encontramos o livro destinado à primeira série.

3 Podem ser encontradas diferentes grafias do nome desse autor, porque a fonética brasileira, por exemplo, é diferente da inglesa. O nome desse autor em língua inglesa é Larichev.

4 Entre 1931 e 1936, o Comitê Central do Partido Comunista de Toda União (bolchevique) (CC PCU [b]) tomou decisões estratégicas e deu orientações para a elaboração de livros didáticos que serviram exclusivamente para os autores desse gênero. Entre os primeiros livros de matemática, encontram-se sob a direção de Elizaveta Savelievna Berezanskaya a obra Seleção de problemas e exercícios de aritmética para escola média (7 anos). Quinto ano de estudo. Moscou, Editora OGIZ/Editora Estatal do Ensino Pedagógico, 1933, 112 páginas; o de Natalia Sergueevna Popova, Livro didático de aritmética para escola inicial. Parte II para segundo ano do ensino. Moscou e Leningrado: Utchpedgiz, 1933; Aleksander Spiridonovitch Ptchelko, com obra intitulada Diretivas metodológicas para livros didáticos estáveis de aritmética para escola primária. Moscou, Utchpedgiz, 1934, 80 páginas; Nikolai Nikiforovitch Nikitin, com obra intitulada Resolução de problemas aritméticos na escola inicial. Moscou, Utchpedgiz, 1939, 108 páginas. 


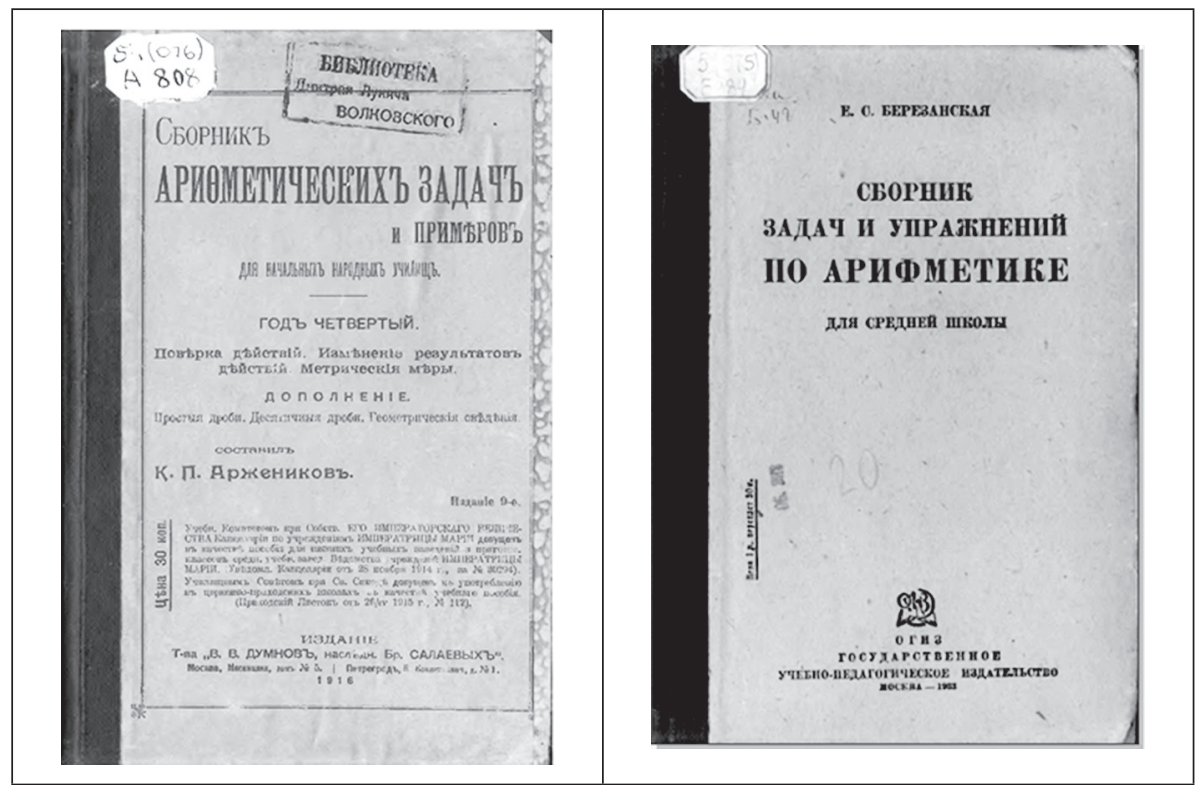

Figura 1 - Seleção de problemas e exemplos de aritmética para séries iniciais das escolas do povo. Quarto ano. (Argennikov, 1916).

Figura 2 - Seleção de problemas e exercícios de aritmética para a escola média (7 anos) (Berezanskaya, 1933).

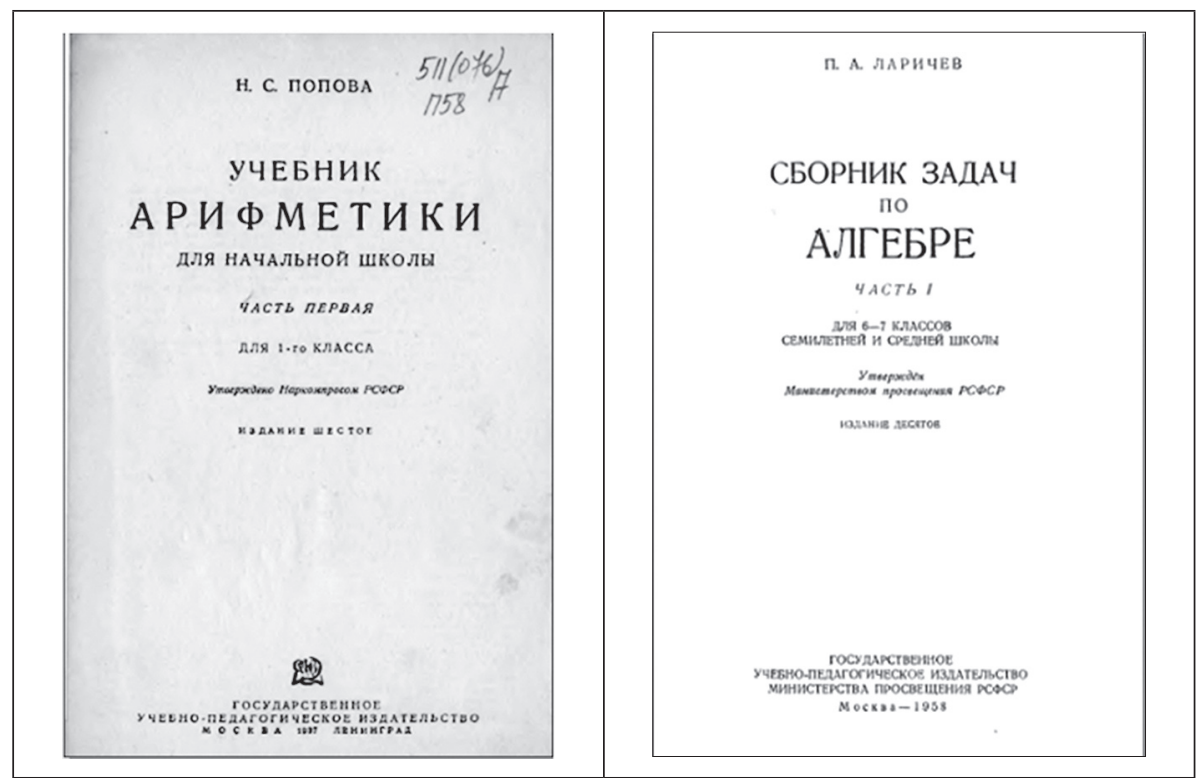

Figura 3 - Livro didático de aritmética para escola inicial (Popova, 1937).
Figura 4 - Seleção de problemas em álgebra. Parte 1 para $6^{\circ}$ $e 7^{\circ}$ anos de escola média (Láritchev, 1958). 
Na presente investigação, para a avaliação dos problemas matemáticos propostos nos livros, lançamos mão das orientações de Minayo (2004) para o entendimento sobre a análise por categorias; por fim, elencamos as seguintes: 1) industrialização; 2) trabalho e área social;3) produção agrícola;4) religiosidade; 5) referências históricas; 6) politização; 7) meios de transporte; 8) corrida espacial.

Para o enquadramento dos problemas nas categorias, levamos em conta o tema predominante, uma vez que alguns deles podiam ser ajustados em mais de uma categoria.

\section{DO CONTEXTO PARA O TEXTO}

No início do século XX, a passagem do regime czarista russo para o soviético foi ao mesmo tempo drástica e violenta. A Revolução Russa, que procurava acabar com a desigualdade social, trouxe mudanças significativas para o país com um preço muito alto. ${ }^{5} \mathrm{~A}$ história da Rússia antiga, usando as próprias palavras de Stalin, ${ }^{6}$ "[...] consiste, aliás, no fato de ter sido permanentemente batida devido ao seu atraso. Foi batida pelos khans mongóis. Foi batida pelos bey turcos. Foi batida pelos feudais suecos". Ao ser instaurado o regime soviético, após a Guerra Civil, tornava-se urgente transformar um país arrasado pelas guerras, com grande contingente populacional analfabeto, num outro, com características diferentes: forte produção agrícola, indústria competitiva na parte civil e bélica e população alfabetizada (Konstantinov; Medynski; Chabaeva, 1982).

O objetivo era muito ambicioso e as dificuldades a serem transpostas enormes, uma vez que as fábricas que restaram após a Guerra Civil operavam com equipamentos antiquados, a base industrial era estreita e o campo fora devastado pelas guerras civis. Além de perdas de potencial humano, os agricultores não possuíam máquinas, havia fome no campo, não havia a possibilidade de empréstimos estrangeiros e ainda todo um povo a "doutrinar".

Para a vitória do socialismo, o partido bolchevique ${ }^{7}$ tinha consciência de que era preciso, de um lado, construir centenas de fábricas de metal-mecânica, recuperar a indústria ligeira e efetuar uma virada para a tecnologia pesada, construir ramos industriais inexistentes, fábricas de máquinas e ferramentas, de automóveis, de produtos químicos, desenvolver motores e equipamentos para as centrais elétricas, aumentar a extração de carvão e metais, construir fábricas de artilharia, munições,

5 Fontes diversas apontam para 5,75 milhões de perdas humanas, apenas na Guerra Civil.

6 Em conferência de 1931, citada na História do Partido Comunista de Toda a Rússia (Comitê Central do Partido Comunista de Toda União [bolchevique], 1938, p. 228).

7 O termo "bolchevique" foi usado pela primeira vez por Lenin, no momento de eleição de dirigentes do Partido Operário Social-Democrata Russo, em 1903, e tem o significado de "maioria partidária", a qual votou em Lenin. Depois da Revolução de Outubro de 1917, surgiram mudanças no nome do partido. No período entre 1925 e 1952, ele foi chamado de Partido Comunista de Toda União (bolchevique). 
de aeronáutica, de tanques e metralhadoras. Por outro lado, era preciso fortalecer a agricultura, composta de 22 milhões de produtores individuais, ${ }^{8}$ acabando com a propriedade privada. Para isso, foram incentivadas à força as organizações coletivas denominadas de kolkhozes e criadas as sovkhozes em prol da coletivação da produção agrícola.

Os kolkhozes (em russo, kollektivnoe khoziaistvo) formavam agremiações comunitárias para explorar os meios de produção que os geriam coletivamente e repartiam os lucros igualmente, mantendo a propriedade de todos. Os sovkhozes (em russo, sovietskoe khoziaistvo) eram instituições do Estado que empregavam seus funcionários com remuneração regulamentada.

Campo e cidade seriam fortalecidos com essas ações, decisivas para a adesão e convencimento das massas populares sobre a superioridade do regime socialista em relação ao capitalista. Mas a implantação dessas medidas na década de 1920 não ocorreu sem resistências. Muitos oponentes foram neutralizados com base na coerção e medo, alguns exilados, ou então violentamente exterminados. Não havia consenso entre os próprios implantadores das novas ideias. $\mathrm{Na}$ longa lista de opositores, encontravam-se nomes como Lev Trotski (1879-1940), Grigori Zinóviev (1883-1936), Karl Rádek (1885-1939), entre outros, transformados em inimigos do Estado. Em 1935, o CC PCU (b) decidiu que sua tarefa era vigiar com intensidade o partido bolchevique para preservar a infiltração de elementos estranhos e hostis (Comitê Central do Partido..., 1938).

\section{A EDUCAÇÃO PRIORIZANDO O TRABALHO}

Após a Revolução Russa, urgia a tomada de medidas para resolver os problemas de analfabetismo e da inexistência de um sistema nacional de educação organizado. Lenin reiterou muitas vezes o significado fundamental da educação do povo para a construção do socialismo, colocando a escola fundamental em primeiro lugar. As diretivas para os comunistas, formuladas pelo Comitê Central, abordavam a posição de Lenin quanto à ligação entre problemas de poder soviético e tarefas políticas e culturais. Ele fundamentava a necessidade de revolução cultural para a vitória do socialismo (idem, p. 233).

Com a revolução, o sistema educacional do período monárquico foi abandonado, bem como os livros didáticos descartados. Em 1918, o sistema escolar adotado já sofria algumas alterações durante a Guerra Civil e com a intervenção estrangeira. Entre essas, foram criadas as faculdades para operários, escolas e clubes para funcionários de idade avançada e escolas de dois anos para crianças fora da

8 Dados extraídos da revista Юные Ударники (Iипye Udarniki. Tradução: Jovens com Desempenho Exemplar no Trabalho), n. 9-10, p. 2, 1932: "A Rússia czarista importava locomotivas a vapor, automóveis, arados, cultivadores. Foram importados até pena, lápis e papel. Havia 22 milhões de produtores individuais agrícolas". Disponível em: <http:// http://mathedu.ru/journals/yunie_udarniki1932-9-10.djvu>. Acesso em: 1 dez. 2010. 
faixa de idade escolar, entre outras. A transição para as condições de paz exigiu a reestruturação de todo o sistema de educação, especificamente da parte de educação profissional. O Comitê Central, ${ }^{9}$ entre 1920 e 1921, decidiu substituir a escola de nove anos de duração por uma escola de sete anos com duas etapas: a primária, com quatro anos; e a secundária, de três anos. E, como forma principal de formação profissional, a técnica foi escolhida em diversas modalidades industriais: agrícola, econômica e pedagógica, com quatro anos de duração (Konstantinov; Medynski; Chabaeva, 1982).

Destacava-se a necessidade de criação de uma rede escolar nas fábricas com o objetivo de formar quadros de funcionários qualificados para a recuperação da indústria. Em contrapartida, havia uma discussão aguda sobre os princípios e fundamentos do sistema escolar, principalmente em relação ao ensino médio. Contudo, a maioria dos pedagogos envolvidos na discussão concordou em substituir a escola total por educação profissional na sua parte básica, média e superior (idem).

Para Lenin (Comitê Central do Partido..., 1938), a redução do tempo escolar de nove para sete anos deveria ser considerada necessidade temporária por causa da pobreza e destruição do país. Ele faleceu no início de 1924 e seus seguidores mantiveram seus ideais.

Em 1928, enfatizou-se o melhoramento radical da segunda etapa da escola básica. O objetivo era preparar os alunos para ingressar nas universidades. $\mathrm{O}$ resultado para a educação soviética foi o surgimento de um novo sistema de educação escolar: primária com quatro anos de estudo; básica ou fundamental de sete anos; e educação de segunda etapa, com nove anos de estudo e ensino profissional. Ainda, existiram escolas de sete anos ligadas às fábricas, especificamente para operários e escolas de camponeses. Essas escolas ofereciam educação média tanto para camponeses quanto operários com o objetivo de ingressar na educação superior. No entanto, para as escolas de camponeses, eram incluídos os conhecimentos de agronomia, até 1934 .

A introdução da educação fundamental obrigatória foi discutida na XVI Reunião do Partido Comunista, em 1930, que criou como força-tarefa a liquidação do analfabetismo. Naquele momento, a alfabetização cresceu bastante, de $33 \%$ em 1916 para 62,6\% em 1930. Menos de um terço da população soviética ainda continuava analfabeta e na área rural essa porcentagem era ainda mais alta. Então, em 14 de agosto de 1930, o CC PCU (b) criou um decreto sobre a educação primária obrigatória de pelo menos quatro anos escolares, para garotos de 8 a 10 anos. Nos mesmos anos, foi introduzida a educação obrigatória para crianças de 11 a 15 anos que não frequentaram os primeiros quatro anos, cursos específicos e escolas especiais. Aquelas que tinham acima de 15 anos foram obrigadas a retornar aos estudos. E, para essa mesma faixa etária, foi introduzida a educação obrigatória de sete anos escolares nos centros industriais, fábricas e zonas industriais. $\mathrm{O}$ decreto

9 O Comitê Central era o do Partido Comunista da Rússia (bolcheviques), PCR (b), como foi chamado o partido comunista de 1918 a 1925. 
obrigava os pais ou tutores a mandarem as crianças para a escola, caso contrário, seriam responsabilizados perante a lei.

A análise dos livros didáticos não pode ser feita alheia à realidade, pois, conforme afirma Faria (2008, p. 77), "eles reproduzem a ideologia dominante". No item a seguir, apresentamos um breve panorama sobre a história dos livros didáticos russos e soviéticos antes de analisarmos aqueles que foram selecionados para esta pesquisa.

\section{DOS LIVROS DIDÁTICOS E SEUS CONTEÚDOS}

O primeiro livro de matemática nacional, publicado em 1703, foi escrito por Leonti Magnistsky (1669-1739), professor da Escola de Ciências Matemáticas e de Navegação, criada por Pedro, o Grande. Essa obra abrangia conteúdos de aritmética, álgebra, geometria e trigonometria, assim como cálculos práticos para o comércio e técnicas de navegação, com a particularidade de abordar temas matemáticos na forma de poesia. Poucos livros didáticos de matemática russos surgiram no século XVIII, intensificando-se sua circulação no século seguinte. Entre 1860 e 1911, foram escritos mais de quarenta livros didáticos de matemática e entre os mais populares encontra-se o de Andrey Petrovitch Kisseliov, citado por Kolyaguin ([200-]). Apesar de boa experiência nas discussões sobre os livros didáticos pela comunidade acadêmica antes de 1917, com a revolução, que rompia não só com um regime político mas também procurava apagar o passado dos czares, a educação deveria ser pautada em novos ideais e por isso os livros didáticos do regime anterior precisavam ser substituídos.

Os textos divulgados nas revistas educativas mostram as ideias políticas que norteavam o CC PCU (b) e revelam a intervenção direta do governo na definição da política educacional. A capa da revista intitulada Para o Livro Didático Bolchervique ${ }^{10}$ é um exemplo, pois já explicita a palavra "bolchevique" destacada em letras vermelhas. $\mathrm{O}$ objetivo era fornecer orientações para os autores de livros didáticos quanto aos conteúdos a serem apresentados e, naturalmente, da ideologia que deveria permear essas obras.

Destacando o crescimento significativo da atividade do professor e da sua responsabilidade pelo trabalho durante os últimos anos, o CC PCU (b) reitera o papel cada vez maior do professor na parte de ensino de crianças sobre os fundamentos das ciências, de educação da obediência consciente e a criação de visão comunista sobre ensino e trabalho (conforme a Decisão do CC PCU (b), de 25 de agosto de 1932).

Em fevereiro de 1933 foi publicado um decreto do CC PCU (b) intitulado Sobre livros didáticos para escola básica e fundamental. ${ }^{11}$ Nele foi desaprovada a

10 Revista За большевистский учебник, Москва, n. 5-6, май-июнь, 1932. Disponível em: <http://mathedu.ru/journals/za_bolshevistskiy_uchebnik1932-5-6.djvu>. Acesso em: 1 dez. 2010.

11 Disponível em: <http://lib4all.ru/base/B3284/B3284Part128-350.php\#>. Acesso em: 23 jan. 2014. 
proposta de criar um livro didático "dinâmico", com conteúdos permanentemente renováveis. A fim de viabilizar essa proposta, o Narcompros (antigo nome do Ministério da Educação) gerou um plano de edição de livros didáticos envolvendo cientistas e teóricos em metodologias de diversas áreas junto com professores de escolas, que acabaram por criar novos livros didáticos para todas as disciplinas da escola soviética de acordo com os novos programas de 1933. Nesse ano, somente na Federação da Rússia foram publicados mais de cem livros didáticos para disciplinas da escola soviética, com tiragem de cinquenta milhões de exemplares; posteriormente esse número cresceu (Konstantinov; Medynski; Chabaeva, 1982).

A maioria dos países europeus experimentou entre os séculos XVIII e XX, na visão de Elias (1997, p. 128), “[...] uma tendência para modificar suas prioridades e seus valores, passando dos ideais humanistas para os nacionalistas. Um exemplo disso foi a Revolução Francesa em 1789".

$\mathrm{Na}$ Rússia - diferente da França, em que a crença nas ideias da revolução passou por um longo período de mudanças -, o partido comunista, ao assumir o poder, procurou reorganizar a sociedade e colocar em prática os ideais de maior igualdade e humanidade o mais rápido possível, na forma de diretrizes e sem dispensar o uso de violência.

Levando em consideração o analfabetismo, a educação em massa então se tornou primazia. De 1884 até 1960, os livros didáticos de matemática adotados na Rússia, referentes à parte teórica, eram aqueles de Andrey Petrovitch Kisseliov (1852-1940). Seu primeiro livro - Curso sistemático de aritmética - foi publicado em 1884, quando ele ensinava matemática nas escolas profissionalizantes. Até 1938, o livro foi reeditado 36 vezes (um milhão e oitocentos exemplares) e a partir daí o número chegou a três milhões de exemplares, pois foi aprovado como de didática estável. Esses livros não priorizavam exercícios e problemas. Para a parte prática havia publicações separadas. A partir da Revolução de 1917, a inclusão de ideologia apareceu principalmente nos livros dedicados a exercícios e problemas (Konstantinov; Medynski; Chabaeva, 1982).

Em nossa análise de livros didáticos editados do período anterior à Revolução de 1917 até os anos de 1960, pretendemos verificar a existência ou não de possíveis mudanças de abordagem dos problemas enunciados nas obras dedicadas ao ensino fundamental de matemática.

\section{ANTES DA REVOLUÇÃO}

Segundo Kolyaguin ([200-]), na véspera da Revolução de 1917, o problema do livro didático não era apenas prerrogativa do Ministério da Educação, mas de toda a comunidade pedagógica, que debateu o conteúdo nos encontros regionais.

$\mathrm{Na}$ capa da nona edição do livro de Argennikov, de 1916, aparece a informação de que o exemplar tinha seu uso indicado para as escolas primárias, escolas preparatórias para o ingresso nas escolas secundárias e para as escolas confessionais. 
$\mathrm{Na}$ obra podemos ler tradicionais enunciados de problemas envolvendo a temática do trabalho no campo, de comércio, e envolvendo a história dos czares. Mas, uma vez que recebeu a permissão de publicação de superiores religiosos, aparecem também problemas que abordam a religião e problemas sociais. Alguns exemplos de problemas envolvendo o trabalho de camponeses com a classe burguesa dos fazendeiros podem ser encontrados nos enunciados ${ }^{12}$ a seguir:

A terra para arar e para o pasto de uma fazenda é de 1.000 desyatin [medida de área usada na Rússia antes da adoção do sistema métrico]. A terra para arar possui 122 desyatin a menos do que o pasto. Quantos desyatin de terra para arar e terra para pasto possui essa fazenda? (Argennikov, 1916, p. 22, problema 7)

Um camponês morou numa cidade por 5 anos. Primeiramente trabalhava como vigia e ganhava 7 rubles [moeda russa] por mês, depois fazia faxina na rua ganhando 9 rubles por mês. Finalmente trabalhou como cocheiro ganhando 12 rubles por mês. Como faxineiro, ele trabalhava seis meses a mais do que como vigia; como cocheiro, seis meses a mais do que como faxineiro. De todo dinheiro que ganhou, gastou na cidade 390 rubles. Quanto dinheiro ele levou para o vilarejo? (idem, p. 24, problema 119)

Enunciados que tratam do comércio podem ser vistos também nessa obra. Note-se que a divisão de classes aparece claramente na referência ao Banco dos Nobres e aos fazendeiros.

Um fazendeiro hipotecou a sua fazenda no Banco Estatal da Terra para Nobres. Ele recebeu o crédito em 40.000 rubles, que deve quitar durante 25 anos, pagando anualmente $6+1 / 2 \%$, incluindo a quitação de dívida. Quanto o fazendeiro deve pagar por ano? Quanto ele vai pagar durante 25 anos? (idem, p. 44, problema 259)

Um comerciante está comprando um pud [16 kg] de querosene pagando 1 rublo e 10 kopeek e está vendendo por 1 rublo e 40 kopeek. Qual o lucro que ele terá nesta venda? Qual o lucro que teria se conseguisse vender 20 kopeek a mais? (idem, p. 24, problema 120)

Um problema relacionado com a religiosidade do povo manifesta-se em um enunciado sobre a peregrina que caminha até um mosteiro.

Uma mulher peregrinou até um mosteiro que fica numa distância de 96 verst [antiga medida de comprimento na Rússia]. Gastou 3 dias, caminhando cada

12 Todos os problemas aqui apresentados, bem como os textos de sites oficiais históricos da Rússia, foram traduzidos do russo para o português por um dos autores deste trabatho, Vladimir Ivanovitch Dynnikov. 
novo dia 8 verst a menos do que no anterior. Qual a distância que ela percorreu em cada dia? (idem, p. 23, problema 116)

Um exemplo sobre a questão de problemas sociais como a escravidão é abordado neste enunciado: "A abolição da escravidão foi declarada no dia 19 de fevereiro de 1861; 2 anos, 1 mês e 29 dias depois saiu proibição de castigo físico. Quando aconteceu essa proibição?” (idem, p. 46, problema 343).

A história russa aparece contemplada nos enunciados, como o que segue. "Ivan, o Terrível, assumiu o trono no dia 17 de dezembro de 1547, enquanto Pedro, o Grande, no dia 21 de outubro de 1721. Quanto tempo se passou entre esses dois eventos?" (idem, p. 50, problema 371).

Os temas dos problemas refletiam as características da vida social na Rússia antes da revolução: trabalho não mecanizado no campo, dificuldade de sobreviver no campo, divisão de classes sociais, baixa renda, lucro no trabalho individual, forte influência dos bancos mesmo para as classes nobres, a religiosidade do povo, memórias recentes sobre a abolição da escravidão e proibição de castigo físico e períodos marcantes da Monarquia. Assim, no exame dessa obra apareceram as primeiras cinco categorias selecionadas.

$\mathrm{Na}$ ação investigativa a seguir, pretendemos verificar se essas temáticas que dizem respeito à vida social permanecem ou não nos enunciados dos problemas matemáticos dos livros escolares, no período pós-revolução.

\section{BEREZANSKAYA - AUTORA DE LIVRO DIDÁTICO A SERVIÇO DO GOVERNO}

As décadas de 1920 e 1930 foram decisivas para a implantação do regime socialista. $O$ primeiro livro selecionado foi publicado pela editora estatal, que tinha o controle do que deveria ser editado no país. Analisando a coleção, constatamos que os problemas eram semelhantes nas diferentes séries e, portanto, poderia ser escolhida qualquer uma delas sem perda de informações. Assim, considerando a maior variedade de tipos de problemas apresentados, optamos por uma coleção para o quinto ano escolar.

No prefácio da obra, Berezanskaya (1933), como autora e organizadora à frente de vários colaboradores, esclarecia que na seleção dos problemas foram usados materiais produzidos antes e depois da Revolução Socialista Soviética. Comparamos os enunciados dos problemas com os textos da História do Partido Comunista da URSS (bolchevique), redigido pelo Comitê Central do PCU em 1938 e também com a história da URSS no mesmo período.

A autora dessa obra - Elizaveta Savelievna Berezanskaya (1891-1969) nasceu no Cáucaso. Foi uma das primeiras professoras de matemática na Rússia, doutora em pedagogia em 1938, participou na criação de métodos nacionais para a escola de ensino médio, foi autora de programas de ensino da matemática para universidades pedagógicas. Berezanskaya introduziu na prática escolar a metodologia 
de exercícios orais como método para despertar o interesse pela matemática; começou sua experiência em escolas profissionalizantes. A obra analisada foi a segunda que editou; a primeira era dedicada à matemática para a indústria têxtil (1926). Posteriormente, escreveu um livro sobre metodologia da aritmética e, em 1960, escreveu como coautora um livro de metodologia da matemática. ${ }^{13}$

No volume analisado não aparecem tópicos teóricos, apenas exercícios e problemas com respostas, num total de 1.337 enunciados. Poucas são as ilustrações no texto e estão reproduzidas no Quadro 1.

Quadro 1 - Ilustrações contidas no livro de Berezanskaya

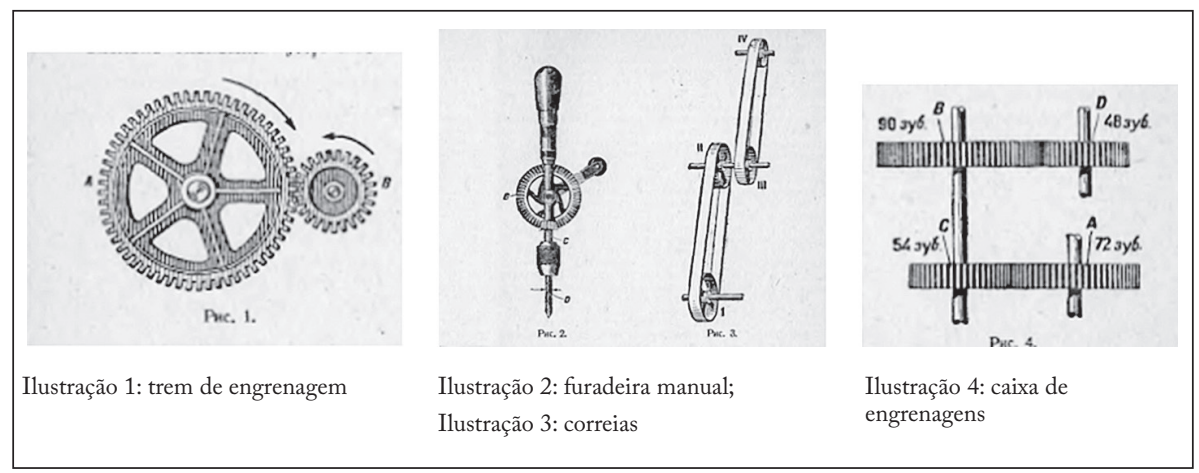

Fonte: Berezanskaya, 1933, p. 84-85.

Elaboração dos autores.

Encontramos enunciados que trazem referências históricas, como a Revolução Francesa, ideário de nacionalismo que repercutiu fortemente na Rússia e seu exemplo foi utilizado para comparação com a Revolução de 1917. Assim, a necessidade de se realizar mudanças sociais por meios revolucionários, usando ou não a violência, era justificada.

Embora a primeira revolução em massa, ocorrida em 1905, tenha sido frustrada, ela foi considerada pelos bolcheviques um marco histórico. Um exemplo desse tipo de problema é apresentado a seguir:

O fuzilamento de operários em Leningrado aconteceu no dia 22 de janeiro de 1905, enquanto a Revolução de Outubro aconteceu no dia 7 de novembro de 1917. Quanto tempo passou entre o fuzilamento de operários e a Revolução de Outubro? (Berezanskaya, 1933, p. 11, problema 88)

Quanto tempo se passou entre a Grande Revolução Francesa e a Revolução de Outubro, se a primeira aconteceu em 1789? (idem, ibidem, problema 89)

13 Fonte: Мир словарей (Mundo de Dicionários Eletrônicos). Disponível em: <http://mirslovarei.com/content_pedslov/berezanskaja-elizaveta-savel-evna-62585.html> . Acesso em: 12 jul. 2010. 
Em relação à categoria industrialização, encontram-se na coleção variadas situações problematizadoras. Era preciso enaltecer, como grandiosa, a edificação industrial que estava sendo implantada. "Foram abertas novas minas e criados novos altos-fornos. Nos Urais construía-se uma fábrica de metal-mecânica e os conglomerados químicos de Berezniki e Solikamsk. Iniciou-se a construção da fábrica metalúrgica de Magnitogorsk" (Comitê Central do Partido..., 1938, p. 216). "Os altos-fornos de Magnitogorsk produziram por dia 1.632 toneladas de ferro fundido de alta qualidade. Quantas toneladas eles poderiam produzir durante um mês?" (Berezanskaya, 1933, p. 12, problema 108).

No relato do partido bolchevique, em que é descrita a luta pela industrialização do país entre 1926 e 1929, observa-se um forte acento na mecanização da agricultura com a criação de fábricas de tratores (Comitê Central do Partido..., 1938, p. 233). Por exemplo:

Um trator pode arar até 250 hectares de terra por ano. Quantos hectares de terra podem ser arados durante um ano por tratores produzidos num dia apenas pela Fábrica de Tratores de Stalingrado, sabendo que ela produz em média 145 tratores por dia? (Berezanskaya, 1933, p. 12, problema 104)

Por trás do texto dessa questão escolar - que fora especificamente elaborada, pois ainda não existia o nome da cidade Stalingrado nem a fábrica de tratores antes da época socialista na Rússia -, encontra-se um tema para o professor explorar conteúdos matemáticos com intuitos políticos e patrióticos.

Vários pontos para cálculos são apresentados procurando demonstrar a vantagem da mecanização na produção agrícola. Um exemplo disso são os dois problemas seguintes:

O custo para arar 3 hectares de terra com um trator Fordson é de 21,75 rubles. Quantos rubles custarão para arar 19 hectares? (idem, p. 81, problema 146)

Arar 5 hectares de terra com cavalo custa 58 rubles. Quantos rubles custarão para arar 19 hectares de terra? (idem, ibidem, problema 147)

A única saída para vencer o atraso da produção agrícola, segundo Stalin (Comitê Central do Partido..., 1938, p. 219), era transformar:

[...] as pequenas explorações camponesas dispersas em grandes explorações unificadas [...] na passagem do cultivo da terra com base em novas técnicas avançadas, [...] na base do cultivo comum, cooperativo e coletivo da terra, com a utilização de maquinaria agrícola, de tratores e de métodos científicos de intensificação da agricultura.

Chamar a atenção para a importância do trabalho coletivo como forma de valorização do homem e progresso do país era mote do partido. A política traçada era ampliar e consolidar o trabalho coletivo nas diversas formas, como os kolkhozes, 
os sorkhozes e as cooperativas. As referências aos sovkhozes aparecem também no enunciado do problema 64 (Berezanskaya, 1933, p. 29): "Um sovkhoz possui 600 hectares de terra. A floresta ocupa $1 / 5$ do total; $2 / 3$ de terra são usados para arar e o resto deixado para pasto. Quantos hectares ocupa o pasto?"

Em referência à categoria meios de transporte, aparecem enunciados sobre as grandes construções com o objetivo de favorecer o desenvolvimento e a sovietização da Ásia Central.

A construção de grandes obras, como estradas de ferro ligando regiões do país, era uma meta do primeiro plano quinquenal (Comitê Central do Partido..., 1938, p. 219). Um exemplo é a construção da ferrovia ligando o Turquestão à Sibéria, que permitia trocar o trigo da Sibéria pelo algodão do sul, mas também havia uma missão logística de facilitar os combates. A parte central da ferrovia foi posta a serviço em 1931 e tinha o comprimento de $1.442 \mathrm{~km}$.

Sobre esse tema, aparece um problema que envolve conteúdos elementares de frações. Nota-se, no enunciado, que os autores preferiram usar uma aproximação $(1.500 \mathrm{~km})$ da extensão da ferrovia.

O comprimento total de trilhos da rota Turquestana-Siberiana (Turksib) é de $1.500 \mathrm{~km}$. De todo cumprimento, $3 / 4$ da rota passa pelo Cazaquistão, enquanto 1/10 pelo Quirquizistão e o restante passa pela Sibéria. Definir quantos quilômetros de Turksib contém o Cazaquistão, o Quirguizistão e a Sibéria. (Berezanskaya, 1933, p. 29, problema 63)

No texto sobre a história do partido comunista da URSS (bolchevique), pouca ênfase é dada à questão do armamento soviético. Brevemente, encontra-se uma frase (Comitê Central do Partido..., 1938, p. 203) chamando a atenção para a necessidade da nova indústria militar para a defesa do país: "Era necessário criar uma nova indústria militar, construir novas fábricas de artilharia, de munições, de aeronáutica, de tanques e de metralhadoras, pois assim exigiam os interesses da defesa da URSS numa situação de cerco capitalista".

No que tange à categoria armamento e preparo militar, encontramos na coleção de Berezanskaya (1933) enunciados de problemas que aparecem como parte da educação militar:

Calcular o peso de munição de rifle, sendo que o cartucho de latão pesa 9 e 3/4 gramas, a pólvora pesa 3 e 3/4 gramas e a bala pesa 9 e 1/2 gramas? (Berezanskaya, 1933, p. 32, problema 94)

A pólvora é composta de carvão, enxofre e salitre. Na preparação foram usados 6 e 3/4 kg de carvão, 3 e 3/5 kg de enxofre e 34 e 13/20 kg de salitre. Quantos quilos de pólvora foram produzidos? (idem, ibidem, problema 95)

Problemas envolvendo armamentos já apareceram em livros didáticos do século XVIII, como o de Etienne Bézout (1730-1783), intitulado Cours de mathématiques à usage du corps royal de l'artillerie, entre 1770-1772. Um exemplo: "Dois morteiros 
atiram bombas, o primeiro atira 40 a mais que o outro. Quantas cada um atira?" (Silva; Sad, 2007).

Todavia, uma diferença deve ser assinalada: esse livro do século XVIII destinava-se à formação matemática de artilheiros, enquanto o livro ora analisado era para a formação geral de jovens soviéticos.

Cumpre destacar que o livro organizado por Berezenskaya (1933), dedicado ao ensino secundário e preparatório para o ensino superior, não foi o único nesse período a incluir ideologia em suas páginas. Apresentamos no item seguinte outra autora que se dedicou à publicação de livros de matemática para as primeiras séries iniciais de ensino. Algumas categorias selecionadas para análise têm enfoque mais forte com essa autora, como a politização e religiosidade. Vejamos então o próximo subtítulo.

\section{POPOVA - LIVROS PARA A ESCOLA PRIMÁRIA SOB A ÉGIDE DO SOCIALISMO}

Natalia Sergueevna Popova (1885-1975), matemática e educadora soviética, foi autora de vários livros e de materiais didáticos para aritmética. Escreveu mais de vinte livros didáticos de matemática com grande tiragem de exemplares e com várias reedições. ${ }^{14}$ No período de 1933 a 1941, Popova escreveu Livros didáticos de aritmética para escola inicial (parte I para primeiro ano; parte II para segundo ano; parte III para terceiro e quarto anos) e Seleção de problemas e exercícios de aritmética para escola inicial (parte I para primeiro ano; parte II para segundo ano; parte III para terceiro ano e parte IV para quarto ano); a parte IV foi escrita em coautoria com Ptchelko. As obras citadas tiveram grandes tiragem e publicadas em várias edições. Foram encontrados e analisados: Livro didático de aritmética para escola inicial, parte I da sexta edição (publicada em 1937), parte II da segunda edição (publicada em 1933) e parte III da quinta edição (publicada em 1937); da Seleção de problemas e exercícios de aritmética para escola inicial, parte II da oitava edição (publicada em 1940), parte III da nona edição (publicada em 1941), parte IV da quarta edição (publicada em 1941). A parte I desse livro não foi encontrada. Em 1959, Popova publicou o livro intitulado Orientação didática para a aritmética. $\mathrm{O}$ parecer para o livro didático para o segundo ano de Popova recebeu o aval de Nadejda Konstantínovna Krúpskaya, esposa de Lenin e famosa por seus trabalhos pedagógicos.

No mesmo ano do lançamento do livro de Berezenskaya, Popova publicou um conjunto de livros didáticos para as séries iniciais (de primeira a quarta série), acompanhado de um conjunto de livros de seleção de problemas e exercícios para cada exemplar.

14 A edição da Seleção de problemas e exercícios de aritmética para escola inicial, parte II, de 1940, alcançou uma tiragem de 1.200.000 exemplares; a parte IV, de 1941, alcançou a tiragem de 1.250 .000 exemplares. 
$\mathrm{Na}$ sexta edição do Livuro didático de aritmética para a escola inicial (parte I, para primeiro ano), em 1937, podemos ler no prefácio a recomendação ao professor para acrescentar problemas por ele formulados com base nos dados regionais para a construção do socialismo.

Observando o livro para a primeira série, nas ilustrações para a aprendizagem dos numerais de 1 a 10 (Quadro 2), além dos objetos e personagens tradicionais, aparecem novos conteúdos, como tratores e aviões, refletindo a industrialização e a mudança de trabalho no campo. Como Faria (2008, p. 79) alerta: "Assim como os exercícios, as ilustrações reforçam o conteúdo ideológico que se quer transmitir". Isso pode ser exemplarmente visto nas imagens do Quadro 2.

Quadro 2 - Ilustrações contidas no livro de Popova

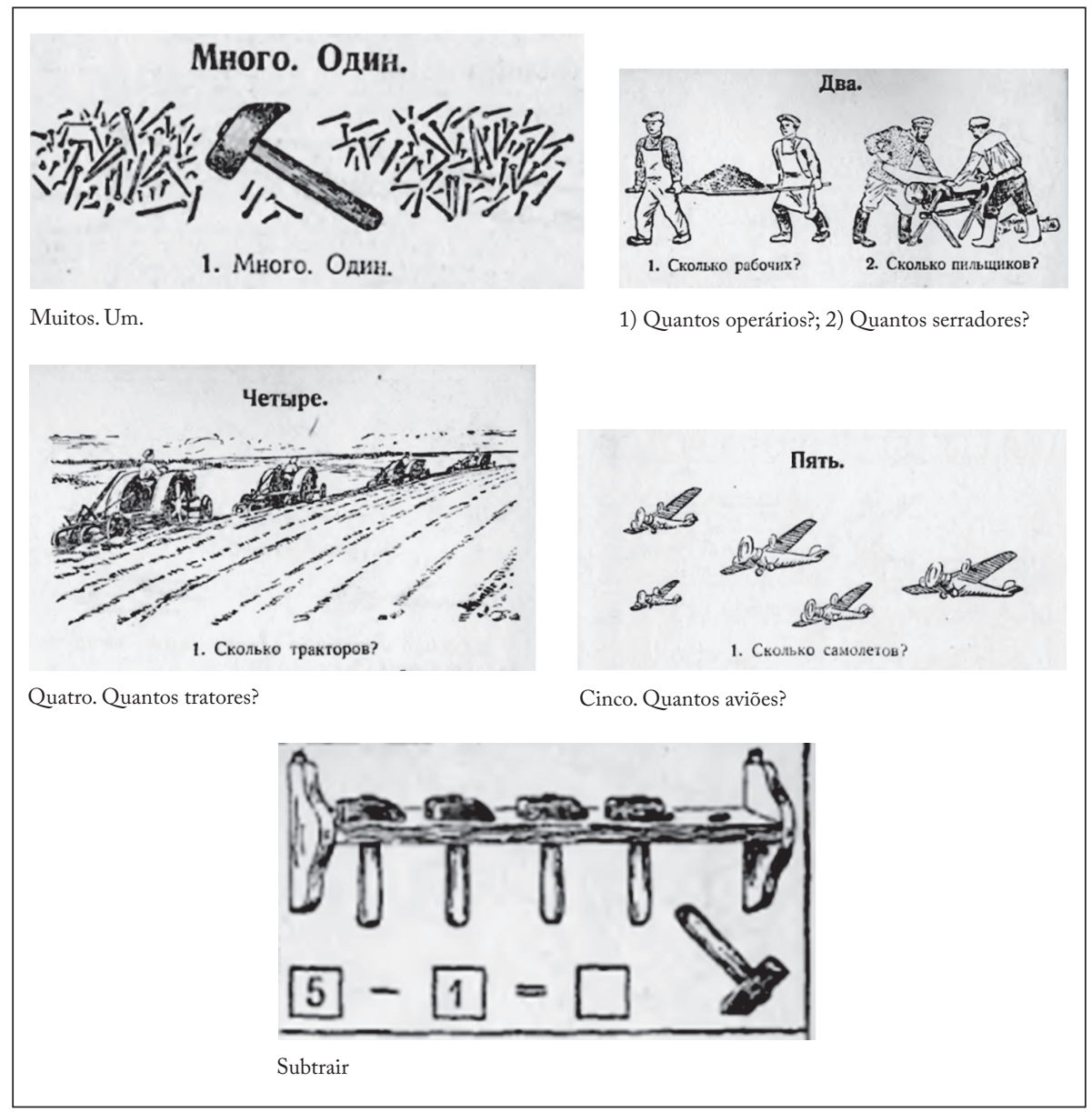

Fonte: Popova, 1937a, p. 3-8.

Elaboração dos autores. 
Na Seleção de problemas e exercícios de aritmética para escola inicial (parte II), encontramos clara referência à categoria politização:

Os operários estudam em três seminários políticos (politkrujok). No primeiro estudam 30 operários, no segundo 26 e no terceiro 10 operários mais do que no primeiro. Quantos operários no total estão estudando nos seminários políticos? (Popova, 1940, p. 3, problema 5)

Tal categoria mereceu maior destaque na obra de Popova (1937a) dedicada ao primeiro ano escolar. Isso pode ser visto na quantidade expressiva de problemas que englobam a terminologia principal da união ideológica desde a infância. Vejamos:

- октябрята (oktyabryata) (p. 32, problemas 9 e 10): crianças seguidoras das ideias de Lenin carregando estrelas no peito com o retrato de Lenin ainda na infância;

- звездочка (zvezdotchka) (p. 40, problema 7): forma de organização dos oktyabryata em grupos de cinco;

- пионер (pioner) (p. 35, problema 2): pioneiros que estão em outra faixa etária de atividades;

- пионеротряд (pionerotryad) (p. 56, problema 1): unidade da estrutura de organização de pioneiros;

- лагерь (lager) (p. 62, problema 7): forma de organização dos pioneiros e colônia de férias até a idade adulta:

- коммунист (kommunist) (p. 57, problema 1): comunista, o topo da hierarquia política.

As mudanças radicais no campo não se restringiram apenas à mecanização. A decisão estatal foi a de transformação de trabalho individual para trabalho coletivo. A referência a esse modo de trabalho apareceu no problema 5, abordando os kolkhoz. "No kolkhoz trabalham 11 mulheres para cuidar dos animais e 8 mulheres que tiram leite. Quantas mulheres trabalham no pátio dos animais?" (idem, p. 27, problema 5).

Além do destaque ao trabalho coletivo, podemos observar a propaganda de mudança no perfil social da mulher, destacando a igualdade com os homens. Outras formas de organização de trabalho coletivo encontram-se nos exemplos do Livro didático de aritmética para escola inicial, na parte II (Leningrado, Utchpedgiz, 1933; segunda edição para segundo ano), tais como: совхоз (sovkhoz) (p. 25, problema 9), ou seja, instituições do Estado que empregavam seus funcionários com remuneração regulamentada, е кооператив (kooperativ) (p. 39, problema 2), o sistema de cooperativa.

Importante citar que, em 1933, os últimos redutos de trabalho individual sofreram ataques maciços do governo.

Na parte II do Livro didático de aritmética para a escola inicial (Popova, 1933), identificamos a categoria religiosidade: 
Calcule quantos colegas da sua turma são membros da União de Jovens Ateus (ЮВБ). Calcule separadamente os rapazes e garotas. Desenhe no caderno duas colunas de quadradinhos, na qual uma coluna representa os ateus rapazes e a outra as garotas ateias. Acima do diagrama, escreva "quantidade de ateus da segunda turma”. Abaixo das colunas, escreva "rapazes”, "garotas". Ao lado do diagrama, defina a escala adotada. (idem, p. 23, problema 2)

A obra de Popova reflete os valores sociais destacados na época. No Livro didático de aritmética para a escola inicial, parte I, (Leningrado, Utchpedgiz, 1937a; sexta edição, para primeiro ano), encontramos enunciados de problemas que se referem à consciência socialista, entre eles a doação voluntária de dinheiro para fabricação de avião (p. 35, problema 2) ou de trabalho mais eficiente superando as metas dos planos, ou seja, ударник (udarnik) (p. 51, problema 1). As vantagens do trabalho na União Soviética aparecem em vários problemas, por exemplo:

Um dia contém 24 horas. Nas fábricas, nos países de burguesia, filhos de operários frequentemente trabalham de 6 horas da manhã até 5 horas da tarde. Quantos horas por dia eles trabalham? (idem, p. 55, problema 3)

Antes de Revolução de Outubro, um operário trabalhava na fábrica de 6 horas da manhã até 6 horas da tarde. Quantos horas trabalhava um operário antes? (idem, ibidem, problema 4)

Durante a gestão do poder soviético, um operário trabalha desde 7 horas da manhã até 3 horas da tarde. Uma hora ele gasta para almoço. Quantos horas trabalha um operário agora? (idem, ibidem, problema 5)

Na parte II da mesma coleção, no Livro didático de aritmética para escola inicial (Popova, 1933), destacamos novamente a referência ao trabalho coletivo, ou seja, школьный участок (horta escolar) (p. 4, problema 1). Além disso, aparecem problemas sobre a consciência socialista na forma de compra de облигация(obligacia), títulos de empréstimo em longo prazo para o governo ${ }^{15}$ (p. 15, problema 4) com uma parte do salário, assim como a doação de dinheiro para fabricação de avião (p. 34, problema 8).

Outros problemas dizem respeito aos planos estatais para cinco anos: пятилетка (руatiletka) (p. 28, problema 4), assim como aqueles de propaganda de operários que se destacam no trabalho na fábrica de automóveis Stalin (завод имени Сталина), сuja nomeação foi feita em homenagem do líder do partido comunista (p. 66, problema 3).

15 A compra desses títulos tornou-se obrigatória na prática, preservando uma parte significativa do salário para o governo. A promessa de restituição de tais títulos não se concretizou em virtude da reforma promovida na época de Nikita Sergueevitch Khruchev. 
A propaganda sobre as vantagens da União Soviética aparece em enunciados no mesmo livro, parte II. Por exemplo:

Nosso adolescente trabalha 4 horas por dia, na China - 14 horas. Quantas horas trabalha nosso adolescente durante 6 dias de trabalho por semana? Quantas horas a menos ele trabalha por semana em relação a dois dias de trabalho de um adolescente chinês? (idem, p. 18, problema 18)

Durante 5 dias de trabalho, um operário chinês trabalha 70 horas, um japonês 60 horas, um alemão 45 horas e o nosso 35 horas. Calcule quantas horas por dia trabalha cada operário e faça um diagrama. (idem, p. 38 , problema 12)

Na parte III da Seleção de problemas e exercícios aritméticos para a escola inicial (Popova, 1941a), aparece uma referência ao trabalho mais eficiente, ou seja, стахановеu (stakhanovets) (p. 310, problema 251). Para destacar os resultados do esforço da industrialização, encontram-se alguns problemas que apontam conquistas marcantes, como o que se segue:

Os aviadores soviéticos partiram de Moscou para os Estados Unidos em 12 de julho de 1937, às 3h21min., e cruzaram o Polo Norte no dia 13 de julho, às $3 \mathrm{~h} 14 \mathrm{~min}$. Todo o voo durou $62 \mathrm{~h} 17 \mathrm{~min}$. Quanto tempo os aviadores soviéticos voaram até o Polo Norte e quando eles aterrissaram nos Estados Unidos? (Popova, 1941a, p. 93, problema 835)

Importante salientar que os livros eram constantemente atualizados, incorporando novidades positivas do país como exemplo citado. De maneira geral, reapareciam as mesmas categorias já indicadas nas edições anteriores. O livro de Popova (1941b) foi escrito em colaboração com Ptchelko, que se dedicou à metodologia de livros didáticos desde 1934 (Ptchelko, 1934).

Apesar da ênfase nos enunciados de problemas sobre o desenvolvimento do país, paralelamente havia uma insistência na obrigatoriedade da preparação militar. Encontramos alguns enunciados a esse respeito (Popova, 1940): стрелковый кружск (strelkory krujok), que significa clube de tiro (p. 10, problema 62); военная учеба (voennaya utcheba) (p. 37, problema 328), referente ao estudo militar, às normas de defesa antiárea e química, cuja sigla em russo é ПВXО (p. 68, problema 615), que são as normas de defesa antiárea e química.

\section{LÁRITCHEV - UM AUTOR DE SUCESSO E A CONTINUIDADE IDEOLÓGICA}

O livro de Láritchev escolhido data de 1958 e é intitulado Seleção de problemas em álgebra (parte I para sexto e sétimo anos de escola média). No volume analisado, não há prefácio ou introdução, nem aparecem tópicos teóricos, apenas exercícios e problemas com respostas, num total de 1.274 enunciados. A parte teórica era 
publicada em obra separada. As ilustrações começam no início da obra, aparecem em forma de desenhos geométricos, muitos gráficos, animais, montes de feno.

O autor Pável Afanássievitch Láritchev (1892-1963) terminou sua formação pedagógica superior em 1918 e começou a ensinar em 1922. Entre 1923 e 1925, realizou estudos no curso de ciência pedagógica superior em Moscou e, segundo ele, gastou vinte anos com sua formação para o magistério. Em 1927, iniciou suas pesquisas para a metodologia do ensino da matemática. Em 1951, Láritchev publicou a obra referida no início desta seção, que alcançou muitas edições, nas quais ele preservou as melhores particularidades: sistematização rigorosa na seleção e interpretação de material, clareza, linguagem sintética e acessibilidade para alunos. ${ }^{16}$

Essa obra foi escrita após a Segunda Guerra Mundial, quando a URSS já havia alcançado uma situação econômica mais estável, a indústria já havia se desenvolvido, a agricultura alcançara padrões excelentes de produção e a fome havia sido controlada. Todavia, a propaganda do regime socialista continuava presente nos livros didáticos de matemática, como podemos constatar nos exemplos de enunciados de problemas da coleção analisada.

No que diz respeito à sexta categoria de problemas, encontramos na coleção aqueles referentes ao trabalho. Os problemas propostos nos livros de matemática serviam para, além do objetivo de exercitar os alunos em cálculos elementares de aritmética, também valorizar as ações dos pioneiros, que acreditavam estar ajudando o governo e cumprindo com seus deveres cívicos.

Pioneiros da escola recolheram $65 \mathrm{~kg}$ de ferro-velho. Cobre e alumínio pesaram $1 \mathrm{~kg}$ a mais que zinco, enquanto cobre pesava $15 \mathrm{~kg}$ a mais que o alumínio. Quantos quilos de cada metal foram recolhidos? (Láritchev, 1958, p. 138, problema 843)

O estímulo de busca de novos métodos de trabalho integrava a formação do estudante. Os problemas revelam uma preocupação em preparar o jovem estudante para situações práticas, envolvendo as habilidades técnicas e também conhecimentos de economia. $\mathrm{O}$ exemplo a seguir ilustra esses objetivos, em que são enaltecidas a dedicação ao trabalho, ultrapassando metas.

Durante oito horas de trabalho, um torneiro mecânico deveria fazer uma quantidade de peças seguindo o plano. Aplicando uma nova ferramenta, ele conseguiu tornear 5 peças a mais em cada hora de trabalho. Por isso, em 6 horas de trabalho ele torneou uma quantidade total de peças em 1,5 vezes maior do que estava previsto pelo plano. Quantas peças por hora foram torneados usando a nova ferramenta? (idem, p. 149, problema 916)

16 Disponível em: <http://www.math.ru/history/people/larichev>. Acesso em: 1 dez. 2010. 
$\mathrm{Na}$ primeira metade da tarefa, um torneiro mecânico trabalhava usando uma ferramenta de aço-carbono. Na segunda metade de tarefa, ele usava uma ferramenta de aço rápido. Assim, toda tarefa foi concluída em 2 horas. No caso de executar 1/3 de tarefa usando a ferramenta de aço-carbono e o restante usando a ferramenta de aço rápido, toda tarefa poderia ser concluída em 1 hora e 50 minutos. Quantas horas ele precisava para terminar a tarefa usando cada vez apenas uma dessas ferramentas? (idem, p. 206, problema 1.248 (1))

Quanto à categoria produção agrícola, encontramos nesse período também um forte apelo ao reflorestamento em volta dos campos, ${ }^{17}$ como estímulo para aumentar a produção da agricultura.

Em 1949, a área total de terra preparada para reflorestamento para defesa de campos tinha um total de 269.600 hectares somando o esforço de kolkhoses, sovkhoses e leskhozes. Entre eles, os kolkhozes prepararam 10 vezes mais do que sovkhoses, e em 84.800 hectares a menos que leskhoses. Quantos hectares da terra foram preparados por kolkhozes, sovkhozes e leskhozes separadamente? (idem, p. 138 , problema 844$)$

Outro exemplo que ilustra a necessidade de manter acesa a chama da propaganda do partido sobre as realizações de sucesso na agricultura está descrito no problema seguinte:

$\mathrm{Na}$ Exposição Nacional agrícola, em 1954, foram exibidas as melhores vacas leiteiras de kolkhozes mais avançados. A produtividade média dessas melhores leiteiras é 3 vezes maior que a de uma leiteira comum. Uma leiteira recordista produziu $7.500 \mathrm{~kg}$ a mais que outras melhores leiteiras e $11.500 \mathrm{~kg}$ a mais que uma leiteira comum. Achar a produtividade da leiteira recordista, de melhores leiteiras e de leiteira comum. (idem, p. 194, problema 1.207)

A obediência à inserção de ideologia do partido continua a aparecer em enunciados de problemas que poderiam ser formulados sem necessariamente fazer essa referência, como o problema 660. "Kolkhoz reservou feno para $t$ dias considerando os gastos diários de $m$ quilogramas. Quantos dias irá durar essa reserva se o gasto diário diminuir em $n$ quilogramas?" Calcular para $\mathrm{t}=120, \mathrm{~m}=500$ e $\mathrm{n}=20$ (idem, p. 111).

A categoria industrialização também aparece, mas nesse período os problemas com tratores não são tão elementares como no período anterior; no entanto, servem para aprofundar conhecimentos em técnicas agrícolas.

Um trator com esteiras, desenvolvendo o esforço de tração de $1.600 \mathrm{~kg}$, está puxando um conjunto de dois cultivadores e de 8 grades do tipo zigue-zague.

17 Trata-se de uma área de proteção do campo de plantio por meio de florestas artificiais no perímetro. 
Definir a resistência de tração de cada cultivador e cada grade se o cultivador possui uma resistência à tração 4 vezes maior que uma grade zigue-zague. (idem, p. 140, problema 859)

Especificamente em relação à quinta categoria, meios de transporte, temos a menção à locomoção em Moscou. Entre as grandes realizações do partido estavam quinze obras, como o metrô de Moscou, destinado ao povo, moderno, eficiente e com bonitas estações, algumas delas verdadeiras obras artísticas. Uma realização que poderia ser vista e usada por todos, tornando-se um símbolo da capacidade do partido em oferecer ao povo conforto e dignidade. A construção começou em 1930 e não visava apenas a ser um rápido e eficiente meio de transporte público para os moscovitas; sua segunda destinação era servir de abrigo no caso de bombardeios. Esta última salvou a vida de muitos cidadãos na Segunda Guerra Mundial. ${ }^{18}$

A propaganda dessa obra monumental é vista também em problemas, como o seguinte:

O comprimento total de quatro escadas rolantes da Linha Gorkovsky do metrô de Moscou é de 280 metros. A menor delas é 24 metros mais curta que a maior de todas. O comprimento da segunda é de 6/7 da maior e de 9/8 da terceira. Achar o comprimento de cada escada rolante. (idem, p. 150, problema 930)

Como os aparelhos de som custavam muito caro na época, a compra conjunta era estimulada. Assim, temos o seguinte exemplo:

Uma turma de amigos resolveu comprar um aparelho de rádio. Se cada um vai gastar 35 rubles, faltarão 30 rubles. Se cada um vai gastar 40 rubles, eles poderão comprar também um conjunto de válvulas eletrônicas de reposição que custa 15 vezes a menos que o próprio aparelho de rádio. Quanto custa esse aparelho? (idem, p. 213, problema 1.270)

Ainda sobre os meios de transporte, incluímos a locomotiva. Nesse período, a locomotiva conhecida como "Maria Fumaça", ou locomotiva a vapor, ainda era a força principal nas ferrovias da URSS.

O peso da locomotiva a vapor abastecida é de 122,8 toneladas. Nela cabe 33 toneladas a mais de água do que combustível, enquanto o peso de locomotiva vazia é 35,8 toneladas a mais do que o de combustível. Definir o peso de água, de combustível e da locomotiva. (idem, p. 196, problema 1.214)

A temática referente à corrida espacial - a luta pela supremacia na conquista do espaço - surge apenas nesse período. Konstantin Tsiolkovsky (1857-1935), professor de matemática e um dos pioneiros da astronáutica, havia demonstrado teoricamente que os foguetes poderiam chegar ao espaço. Em 1915, ele propôs a criação

18 Disponível em: <http://metro.molot.ru/bunker.shtml>. Acesso em: 1 dez. 2010. 
de um motor à base de hidrogênio e oxigênio líquidos como propelentes. Tanto na Alemanha quanto na URSS surgiram grupos que começaram a implantar suas ideias na década de 1930. Mas a Segunda Guerra Mundial foi a principal motivadora para o desenvolvimento de tecnologias que serviram tanto para a guerra como para a corrida espacial. Os alemães tinham alcançado um nível portentoso, tanto na ciência quanto na tecnologia, destacando-se Werhner Magnus Maximilian von Braun (1912-1977), com o desenvolvimento dos foguetes V1 e V2. Americanos e russos aproveitaram esses conhecimentos para o desenvolvimento de foguetes e mísseis.

Embora, nos anos da década de 1940, já tivessem ocorrido ensaios rumo ao espaço, foi na década seguinte que se acirrou a chamada "corrida espacial", quando os Estados Unidos e URSS competiram desenvolvendo tecnologia para conquistar o espaço. A cadela russa Laika foi o primeiro ser vivo no espaço (lançada no Sputnik, em novembro de 1957). Na década de 1960, começaram os voos espaciais tripulados e o russo Yuri Gagarin (1934-1968) foi o primeiro a realizar um voo orbital de 48 minutos na nave Vostok I, em 1961. Um mês depois, os Estados Unidos, atrás nessa corrida, conseguiram colocar em uma aeronave um americano que realizou um voo suborbital. A Lua se tornou uma das metas da corrida. ${ }^{19}$

Podem ser vistas no enunciado do problema questões referentes ao peso de um homem na Lua e na Terra: "Na superfície da Lua, o peso de um corpo é 6 vezes menor que na Terra. Quantos quilos pesaria um homem na Lua se o seu peso na Terra é de 50 quilos maior que na Lua?” (Láritchev, 1958, p. 105, problema 633).

A segunda categoria aparece em enunciados, como o do problema 640 (idem, p. 106), em que a propaganda do partido enaltece o aumento de verbas para as áreas social e cultural. O autor aproveita para explorar os gráficos, conteúdo fortemente presente em todo o livro. Essa é uma diferença marcante em relação ao livro de Berezanskaya, em que os gráficos não são expostos.

Desenhar um gráfico de crescimento de gastos com eventos na área social e cultural na URSS usando os dados da seguinte tabela.

\begin{tabular}{c|r|r|r|r|r}
\hline Anos & $1928-1932$ & $1933-1937$ & $1938-1940$ & $1941-1945$ & $1946-1950$ \\
\hline $\begin{array}{l}\text { Gastos em } \\
\text { bilhôes de } \\
\text { rubles }\end{array}$ & 20,2 & 93,7 & 113,6 & 195,8 & 524,4 \\
\hline
\end{tabular}

No caso desse autor, percebemos certa continuidade ideológica em relação às duas autoras antes analisadas.

19 Disponível em: <http://www.sovkos.ru/>. Acesso em: 12 dez. 2010. 


\section{CONCLUSÕES}

Antes da Revolução Socialista de 1917, a formação ideológica nas escolas explorava os valores da Monarquia, da religião e do trabalho individual. Os enunciados dos problemas nos livros analisados confirmam esse fato. Após a revolução, a intencionalidade dos princípios políticos mudou seu foco. Os dominantes eram outros, sem vínculos com os burgueses e religiosos, os membros responsáveis sobre a ideologia implantada pelo partido comunista impunham ideias às novas gerações por meio dos impressos, em especial os livros didáticos, enaltecendo a supremacia do novo regime político, aquele que deveria resolver os problemas econômicos e sociais do país.

O objeto da intervenção direta era para a massa popular, considerando a quantidade de exemplares dos livros publicados e adotados nas escolas. Especialmente para as séries iniciais, a tiragem desses livros foi de centenas de milhares. Como Thompson (1995) postula, a ideologia é hegemônica e está a serviço da reprodução da ordem social que serve para o favorecimento de grupos dominantes. Constatamos, por meio da obra de Popova, que a inculcação ideológica começava desde o primeiro ano escolar, quando a criança, ainda na idade de 7 anos, tinha os primeiros contatos com o sistema de contagem e com as operações elementares da aritmética.

Comparando os livros didáticos, concluímos que os anteriores à Revolução Socialista apregoavam valores burgueses como o lucro, a iniciativa privada, o trabalho individual, a religiosidade, enquanto os livros da época soviética abandonaram esses valores e começaram a apregoar o trabalho coletivo, o espírito socialista e patriótico pela educação de ateus.

Os autores de livros didáticos pós-revolução que foram analisados aqui seguiram fielmente as diretrizes do CC PCU (b) quanto às orientações metodológicas prescritas e introduziram nos enunciados dos problemas a ideologia que deveria nortear os jovens na nova sociedade e formar uma nova geração de seguidores do poder.

Constatamos, com os exemplos analisados nos livros pós-revolução, que a ideologia estava presente nos enunciados dos livros didáticos de matemática de maneira aberta e direta, a qual tinha como objetivo realçar as realizações na área tecnológica, os progressos na produção agrícola, a superioridade das produções nacionais, as vantagens do trabalho coletivo, as grandes obras nas cidades e os modernos meios de transporte. Os autores desses livros mantinham-se atualizados com as orientações que o partido comunista disseminava e podiam assim incluir exemplos reais nas coletâneas de problemas matemáticos.

Explicitamente, os livros didáticos tornaram-se meios de divulgação da evolução do país e da propaganda política, com um forte acento ao patriotismo e ao conhecimento da história do desenvolvimento político do país depois da Revolução Socialista. Os enunciados dos problemas cumpriram seu papel. 


\section{REFERÊNCIAS}

Althusser, Louis. Ideologia e aparelhos ideológicos do estado. Lisboa: Editorial Presença, 1980.

Argennikov, K. P. Seleção de problemas e exemplos de aritmética para séries iniciais das escolas do povo. Quarto ano. Moscou e Petrogrado: Editora de companhia "V.V.Dumnov, herdeira de Irmãos Salaevykh", 1916.

Berezanskaya, Elizaveta Savelievna. Seleção de problemas e exercícios de aritmética para escola média (7 anos). Quinto ano de estudo. Moscou: Editora OGIZ/Editora Estatal do Ensino Pedagógico, 1933.

Braudel, Fernand. Escritos sobre a história. São Paulo: Perspectiva, 2009.

Comitê Central do Partido Comunista de Toda União [bolchevique] (1938). História do Partido Comunista de Toda a Rússia (bolchevique). Disponível em: <www. hist-socialismo.net>. Acesso em: 12 jul. 2010.

Deiró, Maria de Lourdes Chagas. As belas mentiras: a ideologia subjacente aos textos didáticos. São Paulo: Moraes, 1978.

Elias, Norbert. Os alemães: a luta pelo poder e a evolução do habitus nos séculos XIX e XX. Rio de Janeiro: Jorge Zahar Editor, 1997.

FAria, Ana Lúcia. Ideologia no livro didático. São Paulo: Cortez, 2008.

Kolyaguin, Yuri Mikhailovitch. Livro didático escolar de matemática: ontem, hoje e amanhã. [200-]. Disponível em: <http://www.portal-slovo.ru/art/36369.php>. Acesso em: 2 jan. 2012.

Konstantinov, Nikolai Aleksandrovitch; Medynski, Eugeny Nikolaevitch; Chibaeva, Mariya Fiodorovna. Historia da pedagogia. Moscou: Prosvechenie, 1982.

LÁRItchev, Pável Afanássievitch. Seleção de problemas em álgebra. Parte I para $6^{\circ}$ e $7^{\circ}$ anos de escola média. 10. ed. Moscou: Editora Estatal de Ensino Pedagógico do Ministério de Educação, 1958.

Minayo, Maria Cecília de Souza (Org.). Pesquisa social: teoria, método e criatividade. 23. ed. Petrópolis: Vozes, 2004.

Nikitın, Nikolai Nikiforovitch. Resolução de problemas aritméticos na escola inicial. 4. ed. Moscou: Utchpedgiz, 1939.

Popova, Natalia Sergueevna. Livro didático de aritmética para escola inicial. Parte II para $2^{\circ}$ ano do ensino. 2. ed. Moscou e Leningrado: Utchpedgiz, 1933.

. Livro didático de aritmética para escola inicial. Parte I para $1^{\circ}$ ano. 6. ed. Leningrado: Utchpedgiz, 1937a.

Livro didático de aritmética para escola inicial. Parte III para $3^{\circ}$ e $4^{\circ}$ ano do ensino. 5. ed. Moscou e Leningrado: Utchpedgiz, 1937b.

- Seleção de problemas e exercícios aritméticos para a escola inicial, Parte II para $2^{\circ}$ ano. 8. ed. Leningrado: Editora Estatal de Narcompros, 1940. 
Seleção de problemas e exercícios aritméticos para a escola inicial, Parte III para $3^{\circ}$ ano. 9. ed. Leningrado: Editora Estatal de Narcompros, 1941a.

Popova, Natalia Sergueevna; Pтchelko, Aleksander Spiridonovitch. Seleção de problemas e exercícios aritméticos para a escola inicial, Parte IV para $4^{\circ}$ ano. 4. ed. Leningrado: Editora Estatal de Narcompros, 1941b.

Pтснецко, Aleksander Spiridonovitch. Diretivas metodológicas para livros didáticos estáveis de aritmética para escola primária. Moscou: Utchpedgiz, 1934.

Silva, Circe; SAD, Ligia. Uma abordagem pedagógica do uso de fontes originais em história da matemática. Rio Claro: Gráfica Universitária, 2007.

Thompson, John. Ideologia e cultura moderna: teoria social crítica na era dos meios de comunicação de massa. Petrópolis: Vozes, 1995.

\section{OBRAS RUSSAS ANALISADAS}

АржЕнников, К. П. Сборникъ арифметическихъ задачъ и примеровъ для начальныхъ народныхъ училищъ. Годъ четвертый. Изданіе 9-е. Москва Петроградъ: Товарищество “В. В. ДУМНОВЪ, наследн. Бр. САЛАЕВЫХЪ”, 1916.

БЕРЕЗАНСКАЯ, ЕЛизавета Савельевна. Сборник задач и упражнений по арифметике для средней школьы. Пятый год обучения. Москва: ОГИЗ Государственное учебнопедагогическое издательство, 1933.

Колягин, Юрий Михайлович. Школьный учебник математики: вчера, сегодня, завтра. [200-]. Disponível em: <http://www.portal-slovo.ru/art/36369.php>. Acesso em: 2 jan. 2012.

КонстАнтинов, Николай Александрович; МЕдынский, Евгений Николаевич; ШАБАЕвА, Мария Федоровна. История педагогики. Москва: Просвещение, 1982. ЛАРичев, Павел Афанасьевич. Сборник задач по алгебре. Часть 1. Для 6-7 классов семилетней и средней школь. Издание десятое. Москва: Государственное учебнопедагогическое издательство министерства просвещения РСФСР, 1958.

Никитин, НиколАй Никифорович. Решение арифметических задач в начальной школе. Издание четвертое. Москва: Государственное учебно-педагогическое издательство министерства просвещения РСФСР, 1950.

ПоповА, Наталья Сергеевна. Учебник арифметики для начальной иколь. Часть I. Для 1-го класса. Издание шестое. Москва, Ленинград: Государственное учебнопедагогическое издательство, 1937.

. Учебник арифметики для начальной школь. Часть ІІ. Для второго года обучения. Издание второе. Москва, Ленинград: Государственное учебнопедагогическое издательство, 1933.

. Учебник арифметики для начальной школьл. Часть ІІІ. Для 3-го и 4-го класса. Издание пятое. Москва, Ленинград: Государственное учебно-педагогическое издательство, 1937. 
Сборник арифметических задач и упражнений. Часть II. Для 2-го класса начальной школы. Издание восьмое исправленное и дополненное. Ленинград: Государственное учебно-педагогическое издательство Наркомпроса РСФСР Ленинградское отделение, 1940.

Сборник арифметических задач и упражнений. Часть III. Для 3-го класса начальной школы. Издание девятое. Ленинград: Государственное учебнопедагогическое издательство Наркомпроса РСФСР - Ленинградское отделение, 1941.

ПоповА, Наталья Сергеевна; Пчелко, Александр Спиридонович. Сборник арифметических задач и упражнений. Часть $I V$. Для 4-го класса начальной школы. Издание четвертое. Ленинград: Государственное учебно-педагогическое издательство Наркомпроса РСФСР - Ленинградское отделение, 1941.

Пчелко, Александр Спиридонович. Методическое руководство к стабильным учебникам арифметики для начальной школь. Москва: Государственное учебнопедагогическое издательство, 1934.

\section{SOBRE OS AUTORES}

Circe Mary Silva da Silva é doutora em pedagogia pela Universidade de Bielefeld (Alemanha). Professora da Universidade Federal do Espírito Santo (UFES).

E-mail: circemary@gmail.com

Vladimir Ivanovitch Dynnikov é doutor em automação industrial e robótica pela Universidade Tecnológica Estatal Stankin (Moscou). Professor da Universidade Federal do Espírito Santo (UFES).

E-mail: vladimir174@gmail.com 


\section{CIRCE MARY SILVA DA SILVA E VLADIMIR IVANOVITCH DYNNIKOV}

\section{Ideologia em problemas matemáticos nos livros didáticos soviéticos da pré-revolução até 1960}

A análise dos enunciados de problemas matemáticos em livros soviéticos buscou verificar se houve mudança na ideologia explicitada nos textos antes e após a Revolução de 1917. A análise categorial foi a metodologia de pesquisa para o exame dos problemas em relação ao tema predominante do estudo. Concluímos que antes da revolução a ideologia estava relacionada com o poder da Monarquia russa e da Igreja. A ideologia mudou seu foco e após a revolução os autores de livros didáticos seguiram as diretrizes do Comitê do Partido Soviético. Estas definiam as orientações que deveriam conduzir os jovens russos do primeiro ano escolar até o ensino médio. A ideologia nos enunciados dos livros de matemática de maneira aberta e direta objetivava realçar as realizações na área da tecnologia nacional, progressos na produção agrícola, vantagens do trabalho coletivo, grandes obras nas cidades e modernos meios de transporte.

Palavras-chave: ensino da matemática; ideologia; livros didáticos; Rússia.

Ideology in mathematical problems in soviet textbooks from the pre-revolutionary period to 1960

The analysis of the context of mathematical problems in Soviet textbooks from the pre-revolutionary period to 1960 sought to verify whether there was a change in the ideology made explicit in the texts before and after the Revolution of 1917. We used the categorical analysis as research methodology to examine problems related to the predominant theme of the study. We concluded that, before the revolution, the ideology was related to the power of the Russian monarchy and the Church. Ideology shifted its focus after the revolution: the authors of textbooks followed the guidelines of the Committee of the Communist Party. These defined the orientation that should guide the Russian youth from first grade to secondary education. The ideology in the contents of mathematics textbooks openly and straightforwardly aimed at highlighting the achievements of national technology, the progress in agricultural production, the benefits of collective work, great constructions in the cities and modern means of transport.

Keywords: mathematics teaching; ideology; textbooks; Soviet Russia. 


\section{La ideología de los problemas matemáticos en los libros de texto de la Unión Soviética anterior a la revolución hasta 1960}

El análisis de los estados de problemas matemáticos en los libros soviéticos trató de verificar si habia alguna ideología explicita en los textos antes y después de la Revolución de 1917. Un análisis categórico fue la metodología de investigación para el examen de las cuestiones en relación con el tema predominante del estudio. Llegamos a la conclusión de que antes de la revolución, la ideología se relaciona con el poder de la monarquía rusa y la Iglesia. La ideología ha cambiado su enfoque y después de la revolución, los autores de libros de texto actuaron conforme las directrices del Comité del Partido Soviético. Dichas directrices definian las orientaciones que deberian guiar a los jóvenes rusos desde el primer año escolar hasta la escuela secundaria. La ideología en los enunciados de los libros de matemáticas tenía como objetivo, de forma abierta y directa, destacar los logros en la tecnología nacional, mejoras en la producción agricola, las ventajas del trabajo colectivo, grandes obras en las ciudades y los medios modernos de transporte.

Palabras clave: enseñanza de matemáticas; ideologí; libros de texto; Rusia. 